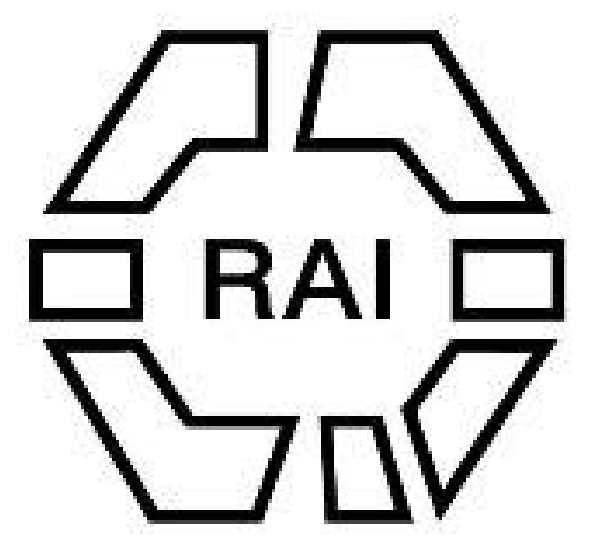

\title{
WILEY
}

\section{On the Stabilty of Unwritten Languages.}

\section{Author(s): R. H. Codrington}

Source: Man, Vol. 3 (1903), pp. 25-26

Published by: Royal Anthropological Institute of Great Britain and Ireland

Stable URL: http://www.jstor.org/stable/2840446

Accessed: 27-06-2016 03:02 UTC

Your use of the JSTOR archive indicates your acceptance of the Terms \& Conditions of Use, available at

http://about.jstor.org/terms

JSTOR is a not-for-profit service that helps scholars, researchers, and students discover, use, and build upon a wide range of content in a trusted digital archive. We use information technology and tools to increase productivity and facilitate new forms of scholarship. For more information about JSTOR, please contact support@jstor.org.

Royal Anthropological Institute of Great Britain and Ireland, Wiley are collaborating with JSTOR to digitize, preserve and extend access to Man 
standard of organization and achievement, and a great sequel of practical applications of many kinds which have been of the profoundest significance in the history of anthropological studies.

JOHN L. MYRES.

\section{Linguistics.}

\section{Codrington.} On the Stabilty of Unwritten Languages. By the Rev. R. H. Cod- 11
rington, D.D.

The recent publication for the Hakluyt Society of the reports of the Spanish discoverers of the Solomon Islands seems to give an opportunity of considering the stability of unwritten languages. It has been commonly believed and stated in books of authority that savage languages, unwritten, uncultivated, without the oral literature of national songs, and without the control of the speech of conquerors or rulers, are subject to continual and very rapid change. Examples have been cited of languages which by such changes have in a very few generations practically disappeared. This belief probably does not hold so strongly as it did, but a test applied to it must be of use, and such a test these reports seem to supply in a remarkable manner.

The Spanish navigators who discovered the Solomon Islands made their reports in 1567 , and recorded several native words. The islands passed at once out of knowledge, and, before very long, almost out of memory. It may be said that no record of the languages of the.group was made for nearly 300 years, when one of the dialects of San Cristoval was learnt and written for missionary purposes. It may be certainly affirmed that Bishop Patteson was the first European who could freely use the native tongues. He wrote and spoke in 1863, when I first saw the Solomon Islands, the language of part of San Cristoval, and that of part of Ysabel, with ease and, as the natives always testified, with correctuess. Before his death, in 1871, he had printed vocabularies and phrase-books in both those dialects, and since that time the language of Florida has become familiar to Melanesian missionaries. Although, therefore, the words recorded more than 300 years ago by the Spanish discoverers are but few, there is abundant knowledge of the present form of the languages to be referred to, if the possessors of such knowledge could be reached.

It is shown, in the introduction to the book, that out of thirty-eight native words recorded by the Spaniards, twenty-two have been identified. Another of some interest I have since observed.*

So far, then, as a very short vocabulary is a test, it is plain that the Solomon Island languages have not undergone much change in 300 years. With all the difficulty of correctly hearing, remembering, and writing down strange words, the Spaniards have recorded what is in great part easily recognised; and it is in vocabulary particularly that uncultivated languages have been believed to be unstable.

But, apart from vocabulary, and even more than from vocabulary, the stability of the Solomon Island language seems to be shown by the still unchanged limits of the dialects which come into view.

1. When the discoverers landed in Ysabel they found two chiefs with their followers, and they do not appear to have been aware that there were two dialects. But the words they recorded can be separated, so far as they can be recognised, into those belonging to one or the other of the two dialects now spoken in the district. It is not merely that there were and are two dialects, very distinct, in that part of a large island, but that both were present, and are present, at the point where the Spaniards made their landfall. They are both where they were and the same that they were.

* Page 311. The natives were laughing in ridicule of the Spaniards, saying May nabolos. Mai is "hither," used by the Spaniards evidently for "bring," and they added their plural $s$, meaning "bring pigs." This is quite the way in which European visitors now speak the native languages. 
2. Again, one of these Ysabel tongues, that of Bugotu, is closely allied to the language spoken in Florida and along the coast of the large island of Guadalcanar up to a certain limit. We find, accordingly, that when the discoverers pass from Ysabel to Florida, they give the native word for "pig"-in the present Florida form-mbolo, not in the Bugotu form, mbotho. The change between those two parallel dialects is shown to have been the same then as now, and with the same boundary.

In the same way a native of Ysabel speaking the Bugotu dialect would at the present time find a form of speech intelligible to him through Florida and along Guadalcanar, but when he arrived at Marau Sound, opposite San Cristoval, he would find that he would cease to be understood; he would have entered the region of the dialects allied with those of San Cristoval. It was so with the interpreters taken in the Spaniards' brigantine ; when they came to the end of the great island and again fell in with the inhabitants, "our people did not understand what they said" (pp. 306,341). It is at this point that the Spanish reports begin to introduce native words belonging to this distinct region of language, words marked by the change of article from na to $a$, and by the appearance of $g u$ to represent $w$ so common in this district, but not heard in Florida, and hardly in Bugotu.

3. Another point may be observed. The Spaniards were struck by the ease with which the Ysabel people pronounced their language (pp. 113, 166). It is remarkable that in Ysabel the sound represented in Spanish by $\tilde{\mathrm{n}}$ is exceedingly common, being generally very rare in Melanesia. The natives do not, like Spaniards, confuse $r$ and $l, b$ and $v$, as those of San Cristoval and Ulawa do, but they would pronounce Mendaña's name exactly ; and Mendaña hearing a native say ini koragna, "here is the middle of it," though he misunderstood it and wrote it yne colanha, has left a bit of the Bugotu language, and of Bugotu grammatical construction, which is perfect now. It may be added that the combination $f, k l, g l$, shown in a few words of the vocabulary is limited now to the district in which the discoverers landed, and that they would hardly find $f$, as in laquifa, elsewhere. It is surely evidence of stability that a language in a small particular area should be tenacious of these sounds.

I may, perhaps, be allowed to add a few notes on points not belonging to language.

1. There can be no doubt, I think, that the "palmettos" cut down for food by the discoverers (p. 143) were sago palms. The Rev. H. Welchman, who has been much in Ysabel, assures me that the natives cut out the pith and cook it for eating. I have seen such sago pith in chunks, cooked for food, in canoes from Tikopia. But the Banks' Islanders and. Santa Cruz people make starch from the pith and eat it in cakes. This is interesting as marking a line of culture, marked also by the use of a loom, which has not touched the Solomon Islands.

2. It is true that lances and arrows tipped with flint are not seen now (p. 351); but pump-drills armed with flint, from the Solomon Islands, may be seen in the British Museum and at Oxford and Cambridge. Dr. Guppy's statement that the natives did not know what the worked flints, common about their places, were, is quite mistaken. A few years ago flakes of flint were in daily use for cutting threads and carving. Bishop Patteson's phrase-book, 1866, shows that arrows tipped with bone were then in common use in Bugotu.

3. Catoira was quite right in saying that caps, i.e., wigs, were made of human hair (p. 351). I have known a man let his hair grow long in order to bave a wig made of it, and $I$ have seen him wear the wig.

4. The savannahs noticed as conspicuous on Guadalcanar (pp. 40, 142) appear also on a much smaller scale in the Banks' Islands. They are permanent.

5. The tusks (p. 33) valued by the natives were undoubtedly the vosa, the tusks of the vena, the dugong, till quite lately of much account in Ysabel. R. H. CODRINGTON. 